\title{
Aphids (Homoptera, Aphidodea) inhabiting the shrubs of Pinus mugo Turra in the green area of Lublin. Part II. Domination and frequency of aphids, their natural enemies and the injuries caused by aphids
}

\author{
ANETA SŁAWIŃSKA, BOŻENNA JAŚKIEWICZ \\ Department of Entomology, University of Agriculture, ul. Leszczyńskiego 7, \\ 20069 Lublin, Poland
}

(Received: 27.01.2004)

Summary

Observations were conducted in the years 1999-2001 on the shrubs Pinus mиgo Turra growing in the green areas of Lublin in two sites (street and park). The purpose of the studies was to establish the domination and frequency of aphids, their effect on the decorative character of shrubs and the occurrence of the aphidophagous arthropods in the aphid colonies inhabiting mountain pine. It was found out that Schizolachnus pineti $\mathrm{F}$. was the dominating species in the street site (A), while Cinara pini L. dominated in the park site (B). The decorative character of shrubs was clearly lowered only by aphids $S$. pineti. Predatory arthropods occurred in aphid colonies inhabiting the shrubs $P$. mugo. Their population in both sites was low, that is why they probably had little influence on limiting the aphid population. Parasitic Hymenoptera of I and II degrees obtained from a culture of aphid mummies were more numerous in the street site.

Key words: Pinus mugo Turra, aphids, domination, frequency, natural enemies, injuries caused by aphids

\section{INTRODUCTION}

This paper is a continuation of studies on the fauna of aphids inhabiting the shrubs of mountain pine (Pinus mugo Turra) presented in Part I. The purpose of the present part (Part II) was to establish the domination and frequency of particular aphid species, to determine their effect on the decorative character of shrubs and the occurrence of predators and parasitoids in the aphid colonies. 


\section{MATERIAL AND METHODS}

The area of studies and the methodology of observing the occurrence of aphids on the shrubs of Pinus mugo Turra in city conditions were discussed in detail in Part I. Besides, in order to establish the qualitative and quantitative relations of particular aphid species occurring on the examined shrubs, two ecological indexes were used, namely domination and frequency (constancy of occurrence) (Górny and Grüm, 1981; Szujecki, 1980; Trojan, 1977).

The index of domination (D) termed as relative abundance $\left(\mathrm{A}_{\mathrm{r}}\right)$ determines the percentage of specimens of a given species in the total number of aphids on the studied plant. The index of domination (D) was calculated according to the following formula:

$$
\mathrm{D}=\frac{n_{\mathrm{a}}}{n} \times 100,
$$

where: $n_{a}$ number of individuals belonging to a given species in all samples,

$n$ number of individuals of a studied systematic group in all samples.

The following classes of domination were distinguished:

Superdominants $>60 \%$

Eudominants $31-60 \%$

Dominants $\quad 21-30 \%$
Subdominants $10-20 \%$

Recedents $\quad 1-9 \%$

Subrecedents $<1 \%$

The index of frequency (F) shows the relation between the number of all samples where a given species occurred and the number of all samples taken from the studied plant. The constancy of occurrence (C), in other words the index of frequency (F) was calculated according to the following formula:

$$
\mathrm{C}=\frac{q}{Q} \times 100
$$

where: $q$ number of trials when a given species was noted,

$Q$ number of all samples.

Four classes of constancy (frequency) were distinguished:

Class I (euconstants)

Class II (constants)

Class III (accessory species)

Class IV (accidents)
0.76-1 (76-100\%)

$$
0.51-0.75(51-75 \%)
$$$$
0.26-0.50(26-50 \%)
$$$$
\leq 0.25(\leq 25 \%) \text {. }
$$

\section{RESULTS}

Fig. 1 presents the percentage of particular aphid species inhabiting the shrubs of Pinus mugo Turra in both sites during the three years of studies. Tab. 1 shows the numbers, domination and frequency of particular aphid species; tab. 2 presents the number of aphid predators, while tab. 3 presents the number of parasitoids and hyperparasitoids. 
site A

site B

\section{Year 1999}
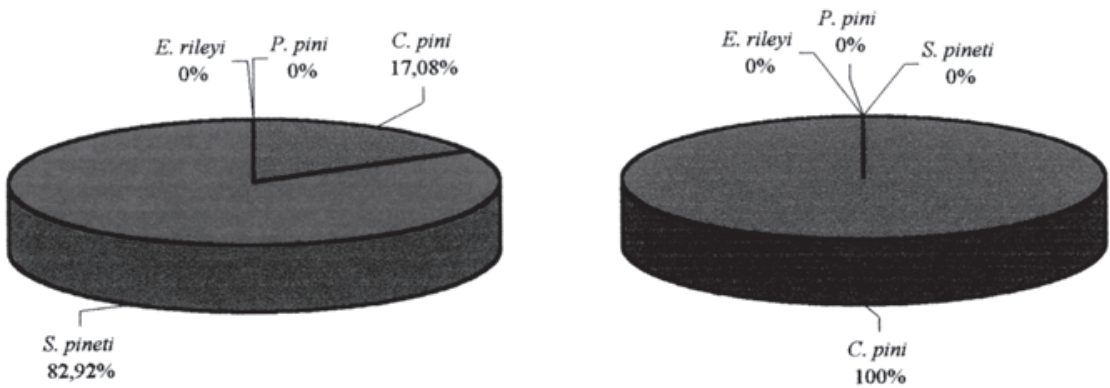

Year 2000
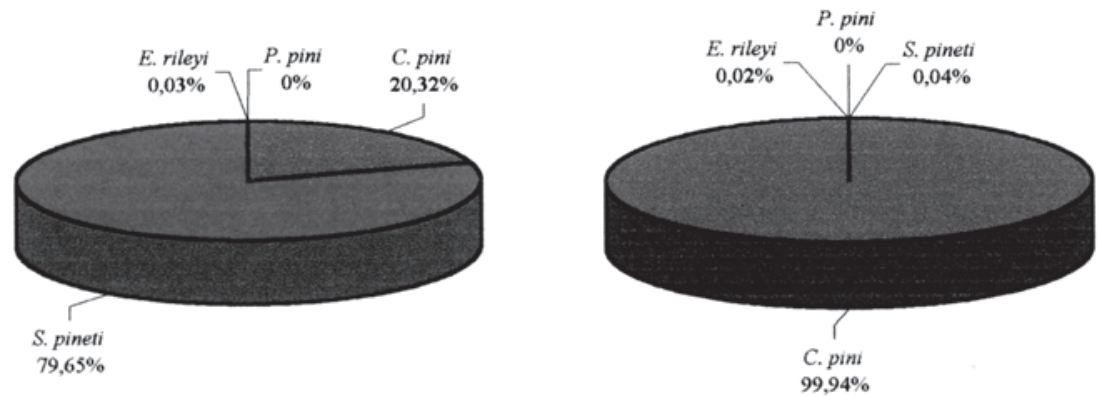

Year 2001
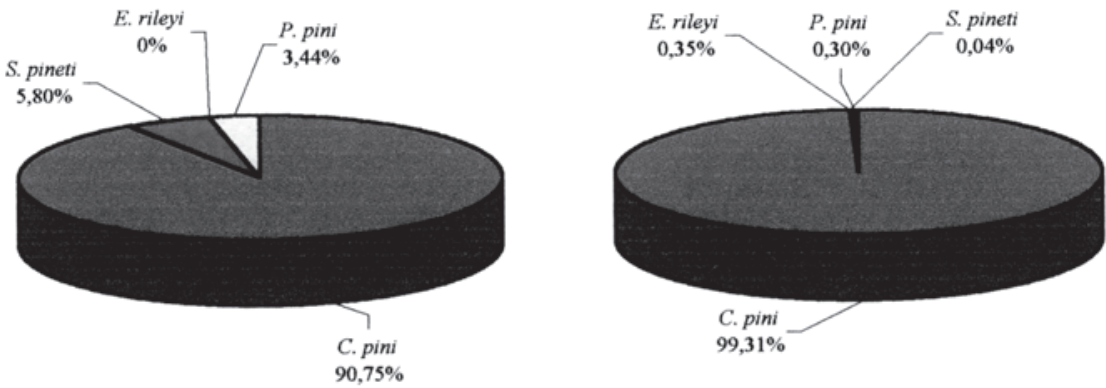

DCinara pini $L$.

DShizolachnus pineti $F$.

DElachnus rileyi (Will.)

a Pineus pini (Ratz.)

Fig. 1. Percent of particular species of aphids on Pinus mugo Turra in the years 19992001 


\section{The structure of domination and frequency of aphids}

Considering all the years of studies, Cinara pini L. in site A was an eudominant and it belonged to class II of frequency constant (Tab. 1). Analyzing each year separately, it was included among the subdominants in 1999 and within class III of frequency an accessory species; in 2000 it was a dominant and belonged to class III of frequency, while in 2001 it was a superdominant and belonged to class I of frequency euconstant. In site B, on the other hand, that aphid was a superdominant every year and it belonged to class I of frequency euconstant. The highest percentage of aphids C. pini was found in 1999 in site B (100\%), while the lowest in the same year in site A $(17.08 \%)$ (Fig. 1).

Table 1. The number, domination and frequency of aphid species inhabiting Pinus mugo Turra in the years 19992001

\begin{tabular}{|c|c|c|c|c|c|c|c|}
\cline { 3 - 8 } $\begin{array}{c}\text { Species of } \\
\text { aphids }\end{array}$ & Year & \multicolumn{4}{c|}{ Site A } & \multicolumn{3}{c|}{ Site B } \\
\hline \multirow{4}{*}{\begin{tabular}{c} 
Cinara pini L. \\
\cline { 2 - 8 }
\end{tabular}} & 1999 & 434 & $17,07(\mathrm{SuD})$ & $0,286(\mathrm{III})$ & 4347 & $100(\mathrm{SD})$ & $0,762(\mathrm{I})$ \\
\cline { 2 - 8 } & 2000 & 1503 & $20,31(\mathrm{D})$ & $0,5(\mathrm{III})$ & 11315 & $99,93(\mathrm{SD})$ & $0,792(\mathrm{I})$ \\
\cline { 2 - 8 } & 2001 & 3190 & $90,75(\mathrm{SD})$ & $0,833(\mathrm{I})$ & 12113 & $99,31(\mathrm{SD})$ & $0,917(\mathrm{I})$ \\
\cline { 2 - 8 } & Total & 5127 & $38,11(\mathrm{E})$ & $0,551(\mathrm{II})$ & 27775 & $99,67(\mathrm{SD})$ & $0,826(\mathrm{I})$ \\
\hline \multirow{4}{*}{$\begin{array}{c}\text { Schizolachnus } \\
\text { pineti F. }\end{array}$} & 1999 & 2107 & $82,92(\mathrm{SD})$ & $0,762(\mathrm{I})$ & 0 & 0 & 0 \\
\cline { 2 - 8 } & 2000 & 5892 & $79,65(\mathrm{SD})$ & $0,667(\mathrm{II})$ & 5 & $0,04(\mathrm{SuR})$ & $0,083(\mathrm{IV})$ \\
\cline { 2 - 8 } & 2001 & 204 & $5,8(\mathrm{R})$ & $0,333(\mathrm{III})$ & 5 & $0,04(\mathrm{SuR})$ & $0,083(\mathrm{IV})$ \\
\cline { 2 - 8 } & Total & 8203 & $60,97(\mathrm{SD})$ & $0,58(\mathrm{II})$ & 10 & $0,03(\mathrm{SuR})$ & $0,058(\mathrm{IV})$ \\
\hline \multirow{4}{*}{$\begin{array}{c}\text { Eulachnus } \\
\text { rileyi }(\text { Will.) }\end{array}$} & 1999 & 0 & 0 & 0 & 0 & 0 & 0 \\
\cline { 2 - 8 } & 2000 & 2 & $0,02(\mathrm{SuR})$ & $0,083(\mathrm{IV})$ & 2 & $0,01(\mathrm{SuR})$ & $0,083(\mathrm{IV})$ \\
\cline { 2 - 8 } & 2001 & 0 & 0 & 0 & 43 & $0,35(\mathrm{SuR})$ & $0,167(\mathrm{IV})$ \\
\cline { 2 - 8 } & Total & 2 & $0,01(\mathrm{SuR})$ & $0,029(\mathrm{IV})$ & 45 & $0,16(\mathrm{SuR})$ & $0,087(\mathrm{IV})$ \\
\hline \multirow{4}{*}{$\begin{array}{c}\text { Pineus pini } \\
\text { (Ratz.) }\end{array}$} & 2999 & 0 & 0 & 0 & 0 & 0 & 0 \\
\cline { 2 - 8 } & 2000 & 0 & 0 & 0 & 0 & 0 & 0 \\
\cline { 2 - 8 } & 2001 & 121 & $3,44(\mathrm{R})$ & $0,167(\mathrm{IV})$ & 36 & $0,29(\mathrm{SuR})$ & $0,083(\mathrm{IV})$ \\
\cline { 2 - 8 } & Total & 121 & $0,89(\mathrm{SuR})$ & $0,058(\mathrm{IV})$ & 36 & $0,12(\mathrm{SuR})$ & $0,029(\mathrm{IV})$ \\
\hline
\end{tabular}

$\mathrm{N}$ Number (in specimens)

C Constancy of aphid appearance:

(I) class I (euconstant)

(II) class II (constant)

(III) class III (accessory species)

(IV) class IV (accident)
D Domination (in \%):

SD superdominant

E eudominant

D dominant

$\mathrm{SuD}$ subdominant

$\mathrm{R}$ recedent

SuR subrecedent 
Schizolachnus pineti $\mathrm{F}$. in site A occurred in all the studied years, while in site B the studies found out its presence only in the years 2000 and 2001. The percentage proportion of those aphids ranged from $0 \%$ to $82.92 \%$, depending on the year of studies and the site (Fig. 1). In the case of aphids of this species there were also some differences in the structure of domination and frequency. In the years 1999 and 2000, in site A it was a superdominant, belonging to class I euconstant and class II constant, respectively. In 2001 it was a recedent included in class III of frequency accessory species. In 1999 this aphid did not appear in site B at all, while in the other years of studies it was a subrecedent and belonged to class IV of frequency accident (Tab. 1).

Pineus pini (Ratz.), especially Eulachnus rileyi (Will.) occurred on the shrubs Pinus mugo Turra only individually and not in each season, and the time of their visit on plants was short. Due to this, those species were included into subrecedents and in class IV of frequency accidents (Tab. 1). The percentage proportion of aphids E. rileyi ranged from $0 \%$ to $0.35 \%$, depending on the year and site, while for aphids P. pini it was between $0 \%$ and $3.44 \%$ (Fig. 1).

\section{Signs of injuries (Photo 1)}

Aphids Cinara pini L. and Schizolachnus pineti F. most frequently inhabited the shrubs Pinus mugo Turra. Aphids $C$. pini inhabited mainly the top shoots of plants, creating colonies composed even of a few hundred individuals. Independently of the

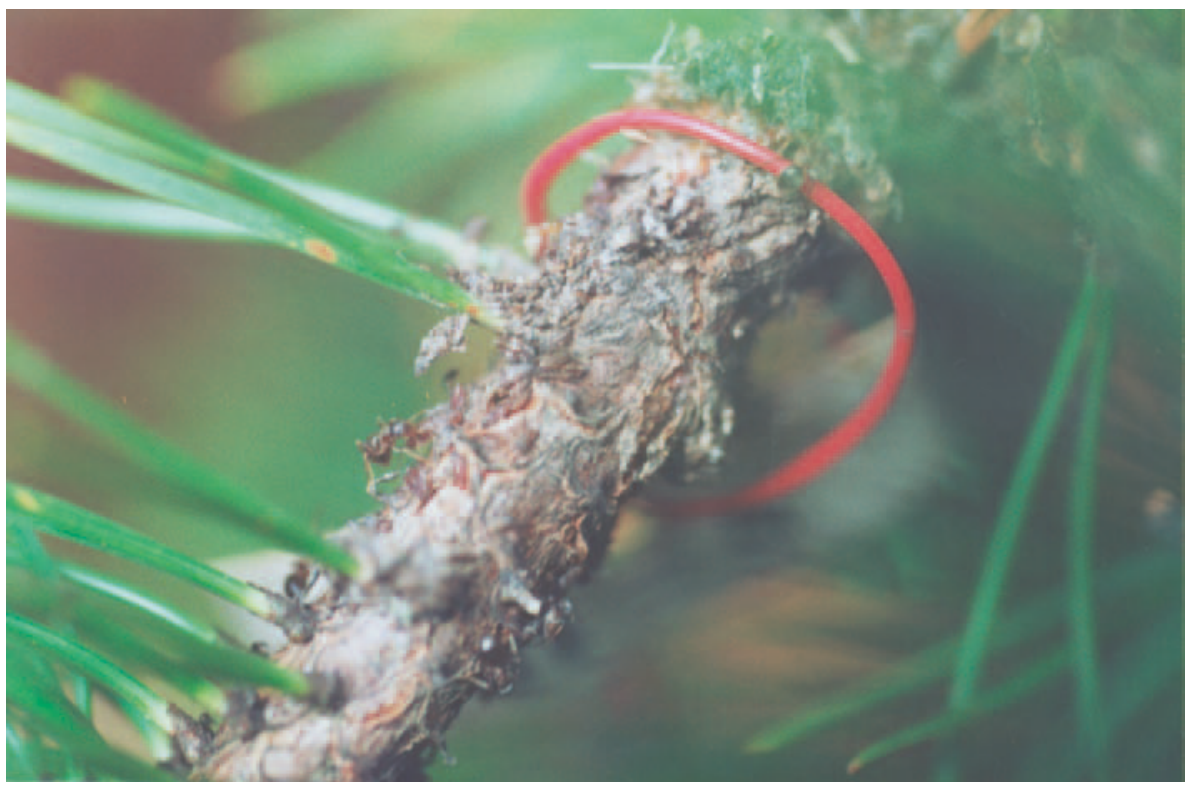

Photo 1. Injuries caused by aphids inhabiting shrubs of Pinus mugo Turra 
Photo 2. Pauesia picta Haliday (Hymenoptera, Aphidiidae) parasitoid of Cinara pini L.

Table 2. The number of aphid predators on Pinus mugo Turra on sites A and B in the years 19992001

\begin{tabular}{|c|c|c|c|c|c|c|c|c|c|}
\hline \multirow{3}{*}{\multicolumn{2}{|c|}{ Predators }} & \multirow{2}{*}{\multicolumn{4}{|c|}{$\frac{\text { Site A }}{\text { Number/shrub }}$}} & \multirow{2}{*}{\multicolumn{4}{|c|}{$\frac{\text { Site B }}{\text { Number/shrub }}$}} \\
\hline & & & & & & & & & \\
\hline & & \multirow{2}{*}{$\begin{array}{c}1999 \\
2,8 \\
\end{array}$} & \multirow{2}{*}{$\begin{array}{c}2000 \\
0,8 \\
\end{array}$} & \multirow{2}{*}{$\frac{2001}{1,6}$} & \multirow{2}{*}{$\frac{\text { Total }}{5,2}$} & \multirow{2}{*}{$\begin{array}{c}1999 \\
0,8\end{array}$} & \multirow{2}{*}{$\begin{array}{c}2000 \\
3,6\end{array}$} & \multirow{2}{*}{2001} & \multirow{2}{*}{$\frac{\text { Total }}{4,4}$} \\
\hline Araneida & young and adult & & & & & & & & \\
\hline Coccinellidae & adult & 2,8 & 3,6 & & 6,4 & 2,4 & 4,8 & 0,4 & 7,6 \\
\hline Dermaptera & larvae and adult & & 0,4 & 0,4 & 0,8 & & & & \\
\hline Syrphidae & larvae & & 1,6 & & 1,6 & & & 2,8 & 2,8 \\
\hline \multirow[t]{2}{*}{ Chrysopidae } & eggs & 2,4 & 1,6 & & 4,0 & 1,6 & 2,8 & 0,4 & 4,8 \\
\hline & adult & & 0,8 & & 0,8 & & & & \\
\hline
\end{tabular}



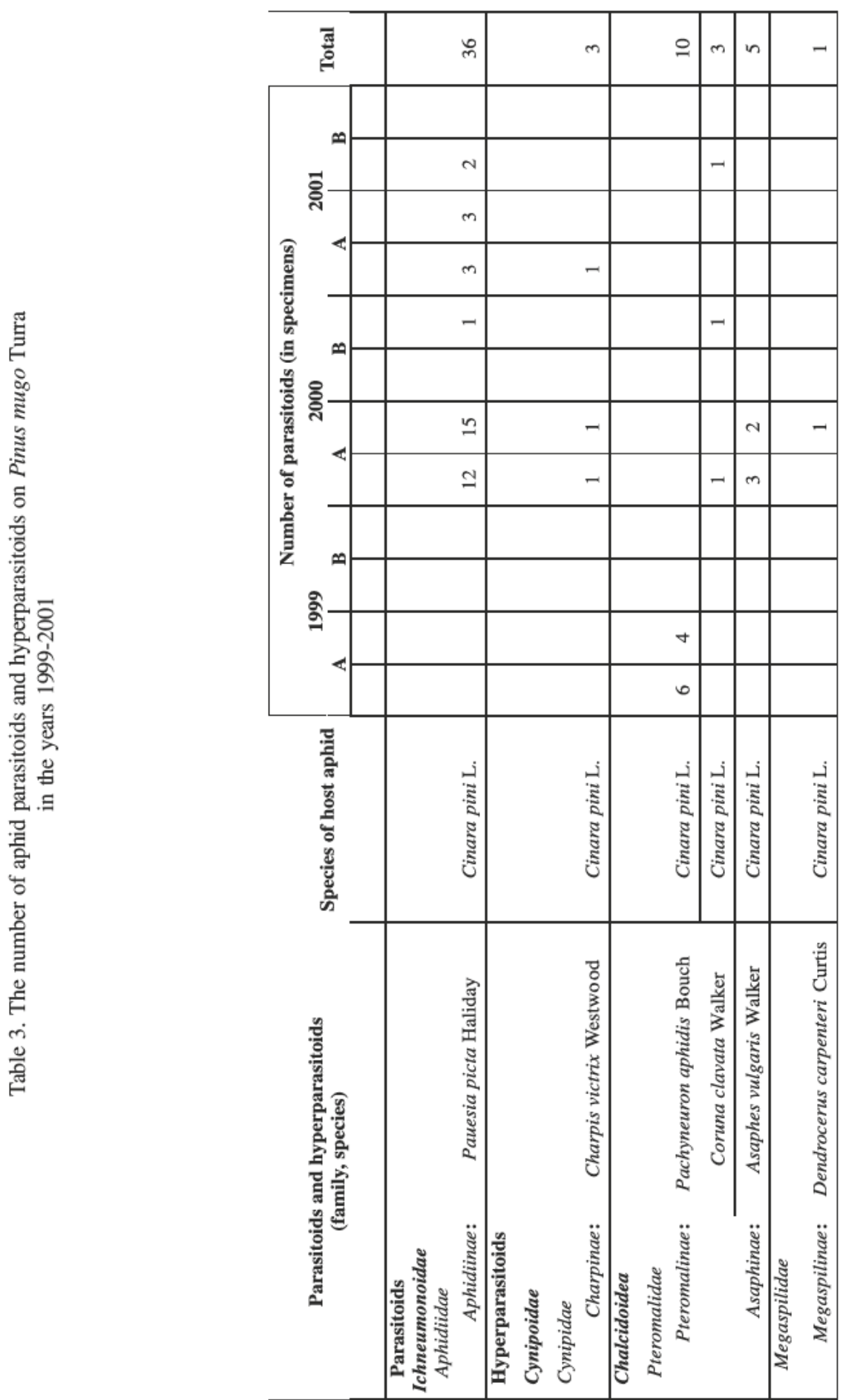
intensity of the colonies, the studies observed no visible injuries caused by the preying aphids. On the other hand, aphids S. pineti preyed on the needles of dwarf mountain pine causing their yellowing and even drying, which remarkably lowered the decorative value of those shrubs and limited their growth. The other two species of aphids Eulachnus rileyi (Will.) and Pineus pini (Ratz.), which were observed only in some years, preyed briefly and scarcely, that is why no clear damage was found out.

\section{Aphidophagous species occurring in aphid colonies}

Observations on the aphid fauna inhabiting the shrubs Pinus mugo Turra found out the presence of predatory arthropods in the aphid colonies, namely young and adult individuals of Araneida; larvae and adults of Dermaptera; adults of Coccinellidae; eggs and adults of Chrysopidae; larvae of Syrphidae (Tab. 2). The total number of all predators in both sites was comparable. Their relatively small number as compared to the considerable number of aphids probably did not have any considerable effect on the decrease of aphid population.

A culture of aphid mummies collected on the shrubs of mountain pine provided the flights of parasitic hymenoptera (Hymenoptera) of I and II degrees (Tab. 3). Only one species was included in the parasitoids of I degree, namely Pauesia picta Haliday from the family Aphidiidae (Photo 2). It attacked only aphids Cinara pini L. The hyperparasitoids included 5 species belonging to 3 families, namely Cynipidae, Pteromalidae and Magaspilidae. The most numerous was Pachyneuron aphidis Bouché from the family Pteromalidae, and its percentage proportion among the parasitoids of II degree was $45.5 \%$. All the parasitic hymenoptera of II degree were obtained exclusively from parasitoid Pauesia picta Haliday, which attacked aphids C. pini.

\section{DISCUSSION}

Among four aphid species preying on mountain pine, Schizolachnus pineti $\mathrm{F}$. was most numerous in the street site (A), while Cinara pini L. was most numerous in the park site (B.).

C. pini was observed on the examined shrubs each year. In site A it belonged to subdominants, dominants or superdominants depending on the year of studies, while in site B it was always a superdominant.

S. pineti occurred in site A in great number; in 1999 and 2000 it was included into superdominants, while in 2000 into recedents.

Scarce aphids $P$. pini occurred in both sites only in 2001, being more numerous in site A. On the other hand, singular specimens of E. rileyi were observed in sites A and B in 2000 and in site B in 2001.

The population of insects with a stinging-sucking mouth apparatus in the city street sites is increasing rapidly. Cichocka and Goszczyński (1991), Jaśkiewicz (2003) and Wilkaniec (1994) report that other aphid species on various decorative shrubs and trees have always been more numerous in the street sites. It was also observed that in those sites the rate of increase of the natural enemies is much slower than that of aphids (Minoranskij and Wojciechowski, 1988). 
A small influence on the decrease of the aphid population was exerted by predatory arthropods due to their small numbers. Depending on the year of studies and the site, Coccinellidae occurred in greater numbers than other predators and their number on a shrub did not exceed 5 in a season. The most numerous species was Adalia bipunctata, which most readily preys on aphids inhabiting shrubs and trees (Iperti, 1965; Pruszyński and Lipa, 1970). Singular larvae of Syrphidae were most frequently observed in June and July, but not in each year of studies. Because of their small number, no effect on the decrease of the aphid population was noticed. Considerable effectiveness of those larvae in limiting the aphids is reported by Dušek and Laška (1966) and Wnuk (1999).

The decorative character of the shrubs of mountain pine was clearly lowered by $S$. pineti, which caused the yellowing of needles and even their drying and it contributed to smaller increases of the shoots. The harmfulness of this species is also pointed to by Łabanowski and Orlikowski (1997). The other aphid species did not cause any visible injuries but they probably weakened the shrubs. On the other hand, Łabanowski et al. (2001) found out that $P$. pini, which preyed on the bark of young shoots or at the base of needles, caused their breaking and premature falling.

Parasitic Hymenoptera of I and II degrees were obtained from the aphid mummies occurring on the shrubs of mountain pine. Parasitoids of I degree included only Pauesia picta Haliday, which attacked exclusively aphids $C$. pini. Werstak and Wiąckowski (1998) found out that this hymenopterous parasitoid of aphids from the genus of Cinara on the trees of common pine (Pinus silvestris L.)

1. During the three years of studies, $S$. pineti was the dominating species in site A, while C. pini on site B.

2. Among the four aphid species inhabiting the shrubs of dwarf mountain pine, only $S$. pineti remarkably decreased the decorative character of plants. Besides, it limited the growth of shoots.

3. The population of predator arthropods in both sites was low, that is why they had only a slight influence on limiting the aphid population.

4. Parasitic Hymenoptera of I and II degrees were more numerous in site A (street site) as compared to site B (park site).

\section{REFERENCES}

Cichocka E., Goszczyński W., 1991. Mszyce zasiedlające drzewa przyuliczne w War szawie. W: Mszyce ich bionomia, szkodliwość i wrogowie naturalni. (red. Cichocka E., Goszczyński W.), PAN, Warszawa, 918.

Dušek J., Laška P., 1966. Occurrence of syrphid larvae on some aphids. Symp. Ecology of Aphidophagous Insects, Prague, 3738.

Górny M., Grüm L., 1981. Metody stosowane w zoologii gleby. PWN, Warszawa, 483pp.

Iperti G., 1965. Comportement naturel des coccinelles aphidiphages du sud est de la Fran ce: leur type de specifite, leur action predatrice sur Aphis fabae L. Entomophaga 11, 2, 203210. 
Jaśkiewicz B., 2003. Occurrence of aphids on Cornus alba L. Acta Sci. Pol. Hortorum Cultus, 2(1), 95110.

Łabanowski G., Orlikowski L., 1997. Ochrona roślin iglastych i wrzosowatych. Plant press Sp. z. o. o., Kraków, 256pp.

Łabanowski G., Orlikowski L., Soika G., Wojdyła A., 2001. Ochrona drzew i krzewów iglastych. Plantpress, Kraków.

Minoranskij V. A., Wojciechowski W., 1988. Wpływ spalin transportu samochodowe go na liczebność mszycy Protaphis artemisiae Narz., biedronki Coccinella septempunc tata L. i mrówki Lasius niger (L.) w strefie przydrożnej. Acta Biol. Sil., Katowice, 10, 27, 2127.

Pruszyński S., Lipa J. J., 1970. Obserwacje nad cyklem rozwojowym i specjalizacją po karmową biedronki dwukropki Adalia bipunctata L. (Coleoptera, Coccinellidae). Pra ce Nauk. Inst. Ochr. Rośl., 12, 2, 99116.

Szujecki A., 1980. Ekologia owadów leśnych. PWN, Warszawa, 603pp.

Trojan P., 1977. Ekologia ogólna. PWN, Warszawa, 418pp.

Werstak K., Wiąckowski S., 1998. Mszycarzowate (Hymenoptera, Aphidiidae) w aglo meracjach miejskich województwa kieleckiego. W: Fauna miast Urban fauna, [red. Barczak T., Indykiewicz P.], Wyd. ATR, Bydgoszcz, 7382.

Wilkaniec B., 1994. Afidofauna of selected tree species in the urban area of Poznań. Aphids and Other Homopterous Insects, 4, PAS, Skierniewice, 7179.

Wnuk A., 1999. Ornamental shrubs n the food chain of aphidophagous Syrphidae (Diptera). W: Protection of plant collections against pests and diseases. vol. I. [(red.) K. Wiech, B. Zemanek], Kraków 2000. Materiały z konferencji w Ogrodzie Botanicznym UJ w Krakowie, 910 września 1999, 4551.

\section{Mszyce (Homoptera, Aphidodea) zasiedlające krzewy Pinus mugo Turra na terenie zieleni miejskiej Lublina. Część II. Dominacja i frekwencja mszyc, ich wrogowie naturalni i powodowane przez mszyce uszkodzenia}

\section{Streszczenie}

Obserwacje były prowadzone w latach 1999-2001 na krzewach Pinus mugo Turra rosnących na terenie zieleni miejskiej Lublina na dwóch stanowiskach (przyulicznym i parkowym). Celem badań było ustalenie struktury dominacji i frekwencji mszyc, ich wpływu na dekoracyjność krzewów oraz występowanie afidofagów w koloniach mszyc zasiedlających sosnę górską. W wyniku przeprowadzonych badań stwierdzono, że na stanowisku przyulicznym (A) gatunkiem dominującym był S. pineti, a na stanowisku parkowym (B) C. pini. Dekoracyjność badanych krzewów wyraźnie obniżały tylko mszyce $S$. pineti. W koloniach mszyc zasiedlających krzewy $P$. mugo występowały drapieżne stawonogi. Ich liczebność na obydwu stanowiskach była niska, dlatego miały one prawdopodobnie niewielki wpływ na ograniczenie populacji mszyc. Pasożytnicze błonkówki I i II stopnia uzyskane w wyniku hodowli mumii mszyc liczniej występowały na stanowisku przyulicznym. 